\title{
Error Correction Model of Inflation in Mongolia
}

\section{Taivan Ulziideleg*}

Supervision Department, Bank of Mongolia (the Central Bank), Ulaanbaatar, Mongolia

\begin{abstract}
This paper investigates the relationship between inflation, money and real output of Mongolia based on data from 1997 to 2006. The error correction model is used to establish the relationship. Causes for inflation would be explained by both approaches: non monetarist and monetarist. Results of the research indicate that there is the relationship between CPI, M2 and GDP. If the growth rate of the Mongolian economy is predictable, then a goal of long run price stability is feasible with the use of M2. In turn, low inflation would create an environment for more rapid economic growth.
\end{abstract}

Keywords: Inflation; Monetary; Consumption; Management; Economy

\section{Introduction}

When discussing about causes of inflation in developing countries one finds that the literature contains two major competing hypotheses. First, there is the monetarist model, which sees inflation as a monetary phenomenon, the control of which requires a control of the money supply as a necessary and sufficient condition such that it grows at a rate consistent with the growth of demand for money with stable prices. The monetarist model is predicated upon the existence of a stable demand for money. An existence of stable demand for money in Mongolia itself might be a disputable proposition due to the numerous deep structural changes and banking crises, which are underway within Mongolian economy since 1990 [1].

Second, non-monetary approach argues that there are non-monetary causes of inflation. These causes featured structural characteristics. Ghatak and Sánchez-Fung [1] demonstrated that there are following structural characteristics. First, relative inelasticity supply of food in developing countries. The supply of essential food commodities may lag behind the demand causing food prices to rise. Second, a fall in world prices of those few export goods would cause a severe shortage of foreign exchange necessary to purchase machinery or oil essential for the smooth functioning of the economies of developing nations. As a result, shortage of industrial essentials will ignite an upward price spirals. Third, the lack of internal financial resources as a distinctive group of reasons causing inflation. Fourth, the shortage of government funding in the sphere of infrastructure is usually solved by inflationary consequences. Kirkpatrick and Nixon [2] fifth, cost inflation, which is derived by the increase in price of production factors, including electricity.

Many models set up in sphere of monetarist approach. Rani [3] run regression between the broad and narrow money aggregates and the inflation rates in India and found that relationship is statistically significant. He used Ordinary least square method (OLS). Paul and Bhanumurthy [4] employ the Vector Auto Regression (VAR) model to investigate relationship between the money supply and price in India and found the money-price relationship exists within that period and is very strong when money aggregate M3, which includes time deposits, is used supporting the monetarist notion of exogenous money supply and the impact of money on prices.

Brada and Kutan [5] used F-tests of running nominal broad money, nominal average wages, and import prices in form of the exchange rate adjusted German whole sale index on the Consumer price index (CPI) in Hungary, Poland and Czech Republic for the period over 1990-1998 to investigate the determinants of inflation in those countries. They show that foreign prices and the persistence of inflation were the key elements of inflation.

Kalra [6] studies inflation and money demand in Albania, which is a small transition economy the size of Mongolia in terms of GDP, between 1993 and 1997. His model supports the claim that determinants of inflation and money demand in transition economies are similar to those in market economies. In particular, for the long run, he establishes a positive relationship between the price level and the exchange rate.

Although, considerable researches have been conducted to identify the factors that influence inflation in transition economies, there has been much less effort in identifying the relationship between these factors and inflation in Mongolia. A question remains how these factors play a role in explaining of inflation. The objective of this study is to examine the impact of the money supply and real output on price.

Results of the research indicate that there is co-integration relation between CPI, M2 and GDP. If the growth rate of the Mongolian economy is predictable, then a goal of long run price stability could be feasible with the use of M2. In turn, low inflation would create an environment for more rapid economic growth. Paper is structured as below. The section 1 gives non-monetary approach for inflation. The section 2 considers monetarist approach for inflation. The section 3 gives discussion. The section 4 considers conclusion and recommendation.

\section{Non-monetary approach}

Similar to other transition economies, Mongolia's relative prices were badly distorted, therefore, the variety of prices, mostly those of energy, food, utilities and rents were taken out of the government control and rapidly liberalized during the first years of reform. Also, there were major fiscal imbalances due to the extensive but unsustainable social expenditure. These imbalances, whose true size was masked by the lack

*Corresponding author: Ulziideleg T, Senior Supervisor, Supervision Department, Bank of Mongolia (the Central bank), Ulaanbaatar, Mongolia, Tel: + 976-11-327093; E-mail: taivan@mongolbank.mn

Received November 14, 2017; Accepted December 01, 2017; Published December 08, 2017

Citation: Ulziideleg T (2017) Error Correction Model of Inflation in Mongolia. Bus Eco J 8: 331. doi: 10.4172/2151-6219.1000331

Copyright: @ 2017 Ulziideleg T. This is an open-access article distributed under the terms of the Creative Commons Attribution License, which permits unrestricted use, distribution, and reproduction in any medium, provided the original author and source are credited. 
of transparency in public sector accounts, were exacerbated by the early phases of reform, including wage adjustments, price liberalization, and exchange rate devaluation. As a result, governments in transition economies have been relatively unwilling to make unpopular decisions to reduce fiscal deficits, which, in turn, acted as the "motor of inflation" [2].

Food items constitute 48 percent of the consumer price index (CPI) in Mongolia, and within these boundaries only meat price makes up 15 percent of whole index. Meat price fluctuations were one of the major changes in the CPI index and those meat price ups and downs were a consequence of seasonal shortages in meat supply during spring and early months of summer when the Mongols consider the meat to be leanest and therefore unsuitable for delivery and consumption.

Mongolia is an exporter of mining products, which are copper, gold and other minerals. A fall in world prices of those few export goods cause a severe shortage of foreign exchange necessary to purchase machinery or oil essential for the smooth functioning of the economies of developing nations. As a result, shortage of industrial essentials will ignite an upward price spirals, which is happened in late 1990s.

Also, one of main reasons of inflation in Mongolia is cost inflation, which is derived by the increase in price of production factors, including electricity. Furthermore, Central bank in Mongolia lacked proper monetary instruments and necessary institutional skell in conducting tight monetary policy, therefore, policy slippages in terms of successfully controlling money supply were unavoidable contributing to the surge in prices (Figure 1).

The inflation in Mongolia declined dramatically from a peak of 325.5 percent in 1992 to 11 and 12.0 in 2005 and 2006 respectfully.

\section{Monetarist approach}

Monetarist approach sees inflation as a monetary phenomenon, control of which requires a control of money supply as a necessary and sufficient condition such that it grows at a consistent with the growth of demand for money with stable prices. The monetarist model is predicated upon the existence of stable money demand for money. In this paper, monetarist model for inflation is developed using error correction model of econometrics.

\section{Data}

In this study monthly statistical data are used. In 1996 and 1998 there were banking crises in Mongolia and as a result three major banks were liquidated. In his research, Frecaut and Sidgwick [7] show

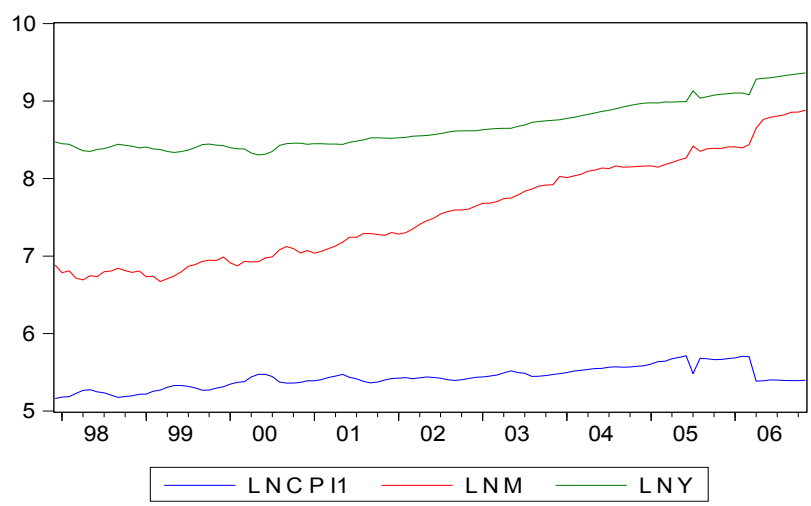

Source: Bank of Mongolia, 2007. http://www.mongolbank.mn/ (2007/01/10).

Figure 1: Dynamic of variables. that Mongolian banks liquidity worsening resulted in some part of the money supply has been lost the negative financial intermediation. Therefore, in order to reduce this negative impact, the monthly statistical data from December 1997 to November 2006 are used [8].

\section{Variables}

P: $\log (\mathrm{CPI}) ; \mathrm{m}:$ money measured $\log (\mathrm{M} 2)$; y: real GDP measured as $\log (\mathrm{GDP} / \mathrm{CPI})$.

\section{Methodology}

According to quantity equation of money, inflation is simply an increase in overall level of prices, and this can be express in term of money exchange equation:

Money velocity $(\mathrm{V}){ }^{\star}$ money supply $(\mathrm{M})=$ Real output $(\mathrm{Y})^{\star}$ Price level $(\mathrm{P})=$ nominal output.

Or $\mathrm{P}=\mathrm{M}^{*} \mathrm{~V} / \mathrm{Y} \Rightarrow \log \mathrm{P}=\log \mathrm{M}+\log \mathrm{V}-\log \mathrm{Y} \Rightarrow \mathrm{p}=\mathrm{m}+\mathrm{v}-\mathrm{y}$.

So price level determined by the rate of growth of the money supply and real output (Table 1).

Table 1 shows that $\log (\mathrm{CPI}), \log (\mathrm{M} 2 / \mathrm{CPI})$ and $\log (\mathrm{Y} / \mathrm{CPI})$ are $\mathrm{I}(1)$ at 1 per cent level of significance [9]. There are two versions of analysis dealing with non-stationary data: regression based on transforming to stationary data through its difference; and co-integration analysis [1013]. In this study, vector error correction model is used.

\section{Results}

\section{Vector error correction model}

Vector error correction mechanism is means of reconciling the short run behaviour of an economic variable with its long term behaviour. In an error correction model, the short-term dynamics of the variables in the system are influenced by the deviation from equilibrium. Since $\log (\mathrm{CPI}), \log (\mathrm{Y})$ and $\log (\mathrm{M})$ are all same level at I(1), the error correction model can be applied. According to Schwarz information criteria, lag length would be 1 (Table 2).

\section{Co-integration test}

Maximum eignevalue test shows that there is co-integration between variables and there is one co-integration equation (Table 3 ).

Co-integration relationship among price, money supply and real GDP.

Long run relationship between $\mathrm{p}, \mathrm{m}$ and $\mathrm{y}$ then estimated by regressing cpi on $\mathrm{m}$ and $\mathrm{y}$ and a constant:

$$
\begin{aligned}
& \mathrm{p}=25.2+1.23^{*} \mathrm{~m}-4.96^{*} \mathrm{y} \\
& \text { s.e. } \quad(0.5) \quad(0.8) \\
& \text { t-stat }(-6.16) \quad(6.17) \\
& \mathrm{R} 2=0.11 .
\end{aligned}
$$

These results are consistent with theoretical expectations. They show that, in the long run, prices rise with an expansion of the money supply but fall with an increase in real GDP. Also, t-ratios for the coefficients of both money and real output are high and significant.

\section{Error correction model of inflation}

Given that there is a co-integral relationship among price, money supply and real GDP, it is possible to specify and estimate an error correction of inflation in the following generic form: 


\begin{tabular}{|c|c|c|c|c|c|c|c|c|c|c|c|}
\hline \multirow[t]{3}{*}{ Indicators } & \multicolumn{4}{|c|}{ No difference } & \multicolumn{4}{|c|}{ First level } & \multicolumn{3}{|c|}{ Second Level } \\
\hline & \multirow[t]{2}{*}{ ADF } & \multicolumn{2}{|c|}{ Test crit.value } & \multirow[t]{2}{*}{$\mathrm{Y} / \mathrm{N}$} & \multirow[t]{2}{*}{ ADF } & \multicolumn{2}{|c|}{ Test crit.value } & \multirow[t]{2}{*}{$\mathrm{Y} / \mathrm{N}$} & \multirow[t]{2}{*}{ ADF } & \multirow{2}{*}{$\begin{array}{c}\text { Test crit.value } \\
1 \%\end{array}$} & \multirow{2}{*}{$\begin{array}{l}\mathrm{Y} / \mathrm{N} \\
5 \%\end{array}$} \\
\hline & & $1 \%$ & $5 \%$ & & & $1 \%$ & $5 \%$ & & & & \\
\hline $\log (\mathrm{CPI})$ & -2.54 & -4.05 & -3.45 & $\mathrm{~N}$ & -11.5 & -3.49 & -2.89 & $Y^{*}$ & & & \\
\hline $\log (\mathrm{M} 2)$ & -3.16 & -4.05 & -3.45 & $\mathrm{~N}$ & -9.04 & -3.49 & -2.89 & $Y^{*}$ & & & \\
\hline $\log (\mathrm{Y} / \mathrm{CPI})$ & -1.09 & -4.05 & -3.45 & $\mathrm{~N}$ & -10.4 & -3.49 & -2.89 & $Y^{*}$ & & & \\
\hline
\end{tabular}

Table 1: Result of stationarity test.

\begin{tabular}{|c|c|c|c|c|c|c|}
\hline Lag & LogL & LR & FPE & AIC & SC & HQ \\
\hline 0 & 140.699 & NA & $1.28 \mathrm{E}-05$ & -2.75398 & -2.67582 & -2.72235 \\
\hline 1 & 716.0004 & 1104.579 & $1.54 \mathrm{E}-10$ & -14.08 & $-13.76739^{*}$ & -13.9535 \\
\hline 2 & 732.0283 & $29.81198^{*}$ & $1.34 \mathrm{e}-10^{*}$ & $-14.22057^{*}$ & -13.6735 & $-13.99915^{*}$ \\
\hline 3 & 739.5001 & 13.44917 & $1.38 \mathrm{E}-10$ & -14.19 & -13.4085 & -13.8737 \\
\hline 4 & 742.5518 & 5.310029 & $1.56 \mathrm{E}-10$ & -14.071 & -13.055 & -13.6598 \\
\hline 5 & 751.0258 & 14.23636 & $1.58 \mathrm{E}-10$ & -14.0605 & -12.81 & -13.5544 \\
\hline 6 & 753.4669 & 3.954548 & $1.82 \mathrm{E}-10$ & -13.9293 & -12.4444 & -13.3284 \\
\hline 7 & 757.934 & 6.968689 & $2.00 \mathrm{E}-10$ & -13.8387 & -12.1193 & -13.1428 \\
\hline 8 & 767.4981 & 14.34616 & $2.00 \mathrm{E}-10$ & -13.85 & -11.8961 & -13.0592 \\
\hline
\end{tabular}

* indicates lag order selected by the criterion

LR: Sequential modified LR test statistic (each test at 5\% level); FPE: Final Prediction Error; AIC: Akaike Information Criterion; SC: Schwarz information Criterion; HQ: Hannan-Quinn information criterion.

Source: Bank of Mongolia, 2005. http://www.mongolbank.mn/ (2006/03/10).

Table 2: Result of lag selection criteria.

\begin{tabular}{|l|c|c|c|}
\hline Unrestricted Cointegration Rank Test (Maximum Eigenvalue) & Max-Eigen Statistic & 0.05 Critical Value & Prob.** \\
\hline Hypothesized No. of CE(s) & Eigenvalue & 23.52558 & 21.13162 \\
\hline None ${ }^{*}$ & 0.199036 & 4.505576 & 14.2646 \\
\hline At most 1 & 0.041615 & 0.0226 \\
\hline At most 2 & 0.003087 & 0.8025 \\
\hline
\end{tabular}

Max-eigenvalue test indicates 1 cointegrating eqn(s) at the 0.05 level; * denotes rejection of the hypothesis at the 0.05 level; ** MacKinnon-Haug-Michelis (1999) p-values.

Source: Bank of Mongolia, 2007. http://www.mongolbank.mn/ (2007/01/10).

Table 3: Results of cointegration test.

$\mathrm{D}(\mathrm{LNCPI})=\mathrm{C}(1) *(\mathrm{LNCPI}(-1)-3.111435599 * \operatorname{LNM}(-1)+4.956138942 * \operatorname{LNY}(-1)-$

$25.21862681)+\mathrm{C}(2) * \mathrm{D}(\mathrm{LNCPI}(-1))+\mathrm{C}(3) * \mathrm{D}(\operatorname{LNM}(-1))+\mathrm{C}(4) * \mathrm{D}(\mathrm{LNY}(-1))+\mathrm{C}(5)$

$\mathrm{dp}=-0.04+3.8^{*} \mathrm{dp}(-1)-0.23^{*} \mathrm{dm}(-1)+4.04^{\star} \mathrm{dy}(-1)+0.05^{\star} \mathrm{u}(-1)$

Adjusted $\mathrm{R}^{2}=0.07$.

Where, $\mathrm{u}(-1)$ is the residual of the co-integrating regression, $\mathrm{d}$ is change in variables. In this specification the error correction term $\mathrm{u}(-1)$ plays the critical role. It measures the speed of adjustment to the cointegrating relationship if the actual relationship deviates from the long term relationship due to disturbance and shocks. The question whether monetary expansion or GDP growth is superfluous in an inflation model can be examined using the Granger causality test.

\section{Granger causality test}

Appendix 1 shows results of Granger causality test. The table indicates that for complete sample period, the null hypothesis that changes in real output not an independent source of inflation would be rejected by $\mathrm{F}$ test at the 1 percent level of significance. It means that GDP growth could be an independent source of inflation. Also, the hypothesis that change in CPI would not led to GDP change would be rejected at 1 percent level of significance. It means that inflation is resulted in the real GDP growth.

\section{Restricted error correction model}

Table 4 shows results of testing hypothesis for restricted error correction model.

\begin{tabular}{|l|c|}
\hline Test results & P-value \\
\hline Long run disequilibrium cannot cause change in dCPI & 0.05 \\
\hline Long run disequilibrium cannot cause change in dM & 0.1 \\
\hline Long run disequilibrium cannot cause change in dY & 0.02 \\
\hline Source: Bank of Mongolia, 2007. http://www.mongolbank.mn/ (2007/01/10). \\
\hline
\end{tabular}

Table 4: Restricted error correction model.

Result of the test shows that hypothesis "CPI would not adjust to changes of one period lagged value of error from co-integrating equations" would be rejected at 5 per cent level. It means that if CPI model out of its long run equilibrium, rise or fall in any of variables, e.g., M2 or Y of co-integrating equation in direction towards its long run equilibrium, would influence CPI change in next period toward its equilibrium. In this case, CPI would be called endogenous.

However, hypothesis "model Y would not adjust to changes of one period lagged value of error from co-integrating equations" would be rejected at 5 percent level. It means that if model out of its long run equilibrium, rise or fall in any of variables, e.g., M2 or CPI of cointegrating equation in direction towards its long run equilibrium, would influence $\mathrm{Y}$ in next period toward its equilibrium. Y would be called endogenous.

Also, hypothesis "model $\mathrm{M}$ would not adjust to changes of one period lagged value of error from co-integrating equations" would be rejected at 10 percent level. It means that if model out of its long run equilibrium, rise or fall in any of variables, e.g., Y or CPI of cointegrating equation in direction towards its long run equilibrium, 
would influence $\mathrm{M}$ in next period toward its equilibrium. $\mathrm{M}$ would be called endogenous.

Thus, each variable adjust to the changes of one period lagged value of error from co-integrating equations. It means if M2 increase price will rise. If price increase, real GDP will fall.

\section{Discussion}

Based on the econometric techniques, some tests have been done taking into account of the inflation model. The equation shows that there is relationship between the inflation, money supply and GDP. The model points to a dominant role of monetary policies in the behaviour of inflation and shows a low persistence of inflation in Mongolia. Both factors contributed to the observed behaviour of inflation.

\section{Conclusion and Recommendation}

Causes for inflation would be explained by both approaches: non monetarist and monetarist. According to non-monetarist approach, Mongolia's relative prices were badly distorted, therefore, the variety of prices, mostly those of energy, food, utilities and rents were taken out of the government control and rapidly liberalized during the first years of reform. Also, there were major fiscal imbalances due to the extensive but unsustainable social expenditure. These imbalances, whose true size was masked by the lack of transparency in public sector accounts, were exacerbated by the early phases of reform, including wage adjustments, price liberalization, and exchange rate devaluation. As a result, governments in transition economies have been relatively unwilling to make unpopular decisions to reduce fiscal deficits, which, in turn, acted as the "motor of inflation".

Moreover, Mongolian economy has explicit seasonality in economic activity picking up in summer and falling during cold winter months. Major price hikes in recent years happened during the spring month caused by interruptions in the supply of meat have been important factor as meat is the main food stable for the Mongols.

Mongolia is an exporter of mining products, which are copper, gold and other minerals. A fall in world prices of those few export goods cause a severe shortage of foreign exchange necessary to purchase machinery or oil essential for the smooth functioning of the economies of developing nations. As a result, shortage of industrial essentials will ignite an upward price spiral, which is happened in late 1990s.

Also, one of main reasons of inflation in Mongolia is cost inflation, which is derived by the increase in price of production factors, including electricity. Furthermore, Central bank in Mongolia lacked proper monetary instruments and necessary institutional skill in conducting tight monetary policy, therefore, policy slippages in terms of successfully controlling money supply were unavoidable contributing to the surge in prices.

Non-monetary approach might be more applicable for analysis of inflationary effects of spring further empirical analysis of inflation in Mongolia.

In line of the monetarist approach, inflation model shows that in the long run, prices rise with an expansion of the money supply but fall with an increase in real GDP. Granger causality test shows that M2 could be an independent source of inflation. Restricted error correction model shows that M2 remain key determinant of the inflation.

This paper has some important implications to the monetary policy. As result suggests money supply M2 can be considered as the viable policy tools against inflation. If the growth rate of the Mongolian economy is predictable, then a goal of long run price stability could be feasible with the use of M2. In turn, low inflation would create an environment for more rapid economic growth.

\section{References}

1. Ghatak S, Sánchez-Fung JR (2007) Monetary economics in developing countries. Palgrave macmillan.

2. Kirkpatrick $\mathrm{CH}$, Nixson FI (1976) The origins of inflation in less developed countries: a selective review. Manchester University Press.

3. Rani PG (1999) Inflation in India: whether classical or non-classical. The Indian Economic Journal 47: 110.

4. Paul MT, Bhanumurthy NR (1999) Money supply, output and price leve relationship in India. The Indian Economic Journal 47: 42.

5. Brada JC, Kutan AM (2002) The end of moderate in three transition economies? William Davidson Institute Working Paper Number 433.

6. Kalra MS (1998) Inflation and money demand in Albania. IMF working paper.

7. Frecaut O, Sidgwick E (1998) Systemic banking distress: The need for an enhanced monetary survey. IMF working paper.

8. Gujarati DN (2004) Basic econometrics. Massachusetts.

9. Hossain MMA (2002) Exchange rate responses to inflation in Bangladesh. IMF Working paper.

10. Parkin M, Zis G (1976) Inflation in open economy. Manchester University Press

11. Sims CA (1980) Macroeconomics and reality. Econometrica 48:1-48.

12. Stock JH, Watson MW (2001) Vector autoregression. The journal of economic perspectives 15: 101-115.

13. Walsh CE (2004) Monetary theory and policy. Second edition, MIT press. 